\title{
Effects of personality traits on severity of sepsis
}

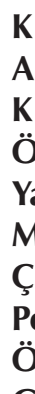 \\ $K$
KA
Ö
Ya
M
Pe
Ö}

Neslihan ÜNAL

$\operatorname{AKDEMIR}^{3}$ (ID)

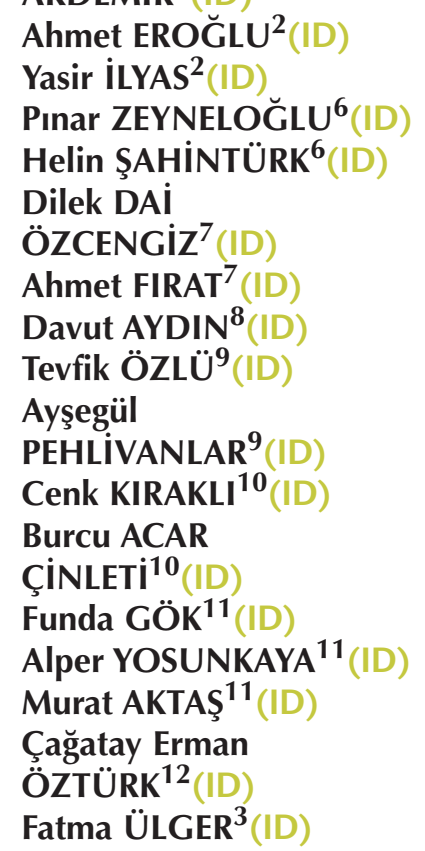

${ }^{1}$ Karadeniz Teknik Üniversitesi Tıp Fakültesi, Göğüs Hastalıkları Anabilim Dalı, Yoğun Bakım Bilim Dalı, Trabzon, Türkiye

${ }^{1}$ Department of Chest Diseases, Division of Intensive Care Medicine, Karadeniz Technical University Faculty of Medicine, Trabzon, Turkey

${ }^{2}$ Karadeniz Teknik Üniversitesi Tıp Fakültesi, Anesteziyoloji ve Reanimasyon Anabilim Dalı, Yoğun Bakım Bilim Dalı, Trabzon, Türkiye

${ }^{2}$ Department of Anesthesiology and Reanimation, Division of Intensive Care Medicine, Karadeniz Technical University Faculty of Medicine, Trabzon, Turkey

${ }^{3}$ Ondokuz Mayıs Üniversitesi Tıp Fakültesi, Anesteziyoloji ve Reanimasyon Anabilim Dalı, Yoğun Bakım Bilim Dalı, Samsun, Türkiye

${ }^{3}$ Department of Anesthesiology and Reanimation, Division of Intensive Care Medicine, Ondokuz Mayıs University Faculty of Medicine, Samsun, Turkey

${ }^{4}$ İstanbul Üniversitesi Cerrahpaşa-Cerrahpaşa Tıp Fakültesi, Anesteziyoloji ve Reanimasyon Anabilim Dalı, Yoğun Bakım Bilim Dalı, İstanbul, Türkiye

${ }^{4}$ Department of Anesthesiology and Reanimation, Division of Intensive Care Medicine, Istanbul University Cerrahpaşa-Cerrahpaşa Faculty of Medicine, istanbul, Turkey

${ }^{5}$ İstanbul Üniversitesi İstanbul Tıp Fakültesi, Anesteziyoloji ve Reanimasyon Anabilim Dalı, Yoğun Bakım Bilim Dalı, İstanbul, Türkiye

${ }^{5}$ Department of Anesthesiology and Reanimation, Division of Intensive Care Medicine, Istanbul University Istanbul Faculty of Medicine, Istanbul, Turkey

${ }^{6}$ Başkent Üniversitesi Tıp Fakültesi, Anesteziyoloji ve Reanimasyon Anabilim Dalı, Yoğun Bakım Bilim Dalı, Ankara, Türkiye

${ }^{6}$ Department of Anesthesiology and Reanimation, Division of Intensive Care Medicine, Başkent University Faculty of Medicine, Ankara, Turkey

${ }^{7}$ Çukurova Üniversitesi Tıp Fakültesi, Anesteziyoloji ve Reanimasyon Anabilim Dalı, Yoğun Bakım Bilim Dalı, Adana, Türkiye

${ }^{7}$ Department of Anesthesiology and Reanimation, Division of Intensive Care Medicine, Çukurova University Faculty of Medicine, Adana, Turkey

${ }^{8}$ Sağlık Bilimleri Üniversitesi, Kanuni Eğitim ve Araştırma Hastanesi, Yoğun Bakım Kliniği, Trabzon, Türkiye

${ }^{8}$ Clinic of Intensive Care, Kanuni Research and Training Hospital, University of Health Sciences, Trabzon, Turkey

${ }^{9}$ Karadeniz Teknik Üniversitesi Tıp Fakültesi, Göğüs Hastalıkları Anabilim Dalı, Trabzon, Türkiye

${ }^{9}$ Department of Chest Diseases, Karadeniz Technical University Faculty of Medicine, Trabzon, Turkey

${ }^{10}$ Sağlık Bilimleri Üniverstesi, İzmir Suat Seren Göğüs Hastalıkları ve Cerrahisi Eğitim Araştırma Hastanesi, Yoğun Bakım Kliniği, İzmir, Türkiye

${ }^{10}$ Clinic of Intensive Care, Izmir Suat Seren Chest Diseases and Surgery Training and Research Hospital, University of Health Sciences, İzmir, Turkey 
Cite this article as: Pehlivanlar Küçük $M$, Küçük $A O$, Kömürcü Ö, Dikmen $Y$, Kadıŏlu M, Uzan ÇA, et al. Effects of personality traits on severity of sepsis. Tuberk Toraks 2021;69(3):349-359.

\section{Address for Correspondence (Yazışma Adresi)}

Dr. Mehtap PEHLIVANLAR KÜÇÜK

Department of Chest Diseases, Division of Intensive Care Medicine, Karadeniz Technical University Faculty of Medicine

TRABZON - TURKEY

e-mail: mehtap_phlvnlr@hotmail.com
11 Necmettin Erbekan Üniversitesi Meram Tıp Fakültesi, Anesteziyoloji ve Reanimasyon Anabilim Dalı, Yoğun Bakım Bilim Dalı, Konya, Türkiye

11 Department of Anesthesiology and Reanimation, Division of Intensive Care Medicine, Necmettin Erbakan University Meram Faculty of Medicine, Konya, Turkey

${ }^{12}$ Sağlık Bilimleri Üniversitesi, Samsun Eğitim ve Araştırma Hastanesi, Anesteziyoloji ve Reanimasyon Kliniği, Samsun, Türkiye

12 Department of Anesthesiology and Reanimation, University of Health Sciences, Samsun Research and Training Hospital, Samsun, Turkey

CCopyright 2021 by Tuberculosis and Thorax.

Available on-line at www.tuberktoraks.org.com

\section{ABSTRACT}

\section{Effects of personality traits on severity of sepsis}

Introduction: The aim of this study was to reveal the effect of the individual's lifestyle and personality traits on the disease process in patients with sepsis and to have clinical predictions about these patients.

Materials and Methods: The study was planned as a multi-center, prospective, observational study after obtaining the approval of the local ethics committee. Patients were hospitalized in different intensive care units. Besides demographics and personal characteristics of patients, laboratory data, length of hospital and ICU stay, and mortality was recorded. Two hundred and fifty-nine patients were followed up in 11 different intensive care units. Mortality rates, morbidities, blood analyses, and personality traits were evaluated as primary outcomes.

Results: Of the 259 patients followed up, mortality rates were significantly higher in men than in women ( $p=0.008)$. No significant difference was found between the patients' daily activity, tea and coffee consumption, reading habits, smoking habits, blood groups, atopy histories and mortality rates. Examining the personal traits, it was seen that 90 people had A-type personality structure and 51 $(56.7 \%)$ of them died with higher mortality rate compared to type $B(p=0.038)$. There was no difference between personalities, in concomitant ARDS occurrence, need for sedation and renal replacement therapies.

Conclusion: Among individuals diagnosed with sepsis/septic shock, mortality increased significantly in patients with A-type personality trait compared to other personality traits. These results showed that personal traits may be useful in predicting the severity of disease and mortality in patients with sepsis/septic shock.

Key words: Intensive care; mortality; personality types; sepsis; septic shock

\section{ÖZ}

\section{Kişilik özelliklerinin sepsis şiddetine etkileri}

Giriş: Bu çalışmanın amacı, sepsis hastalarında bireyin yaşam tarzı ve kişilik özelliklerinin hastalık sürecine etkisini ortaya çıkarmak ve bu hastalar hakkında klinik öngörülerde bulunmaktır.

Materyal ve Metod: Çalışma yerel etik kurul onayı alındıktan sonra çok merkezli, prospektif, gözlemsel bir çalışma olarak planlandı. Hastaların demografik ve kişisel özelliklerinin yanı sıra laboratuvar verileri, hastanede ve yoğun bakım ünitesinde kalış süreleri ve ölüm oranları kaydedildi. iki yüz elli dokuz hasta 11 farklı yoğun bakım ünitesinde izlendi. Birincil çıktılar: ölüm oranları, hastalıklar, kan analizleri ve kişilik özellikleri olarak araştırıldı.

Bulgular: iki yüz elli dokuz hasta takip edildi. Erkeklerde ölüm oranları kadınlara göre anlamlı olarak daha yüksekti $(p=0,008)$. Hastaların günlük aktiviteleri, çay ve kahve tüketimi, okuma alışkanlıkları, sigara içme alışkanlıkları, kan grupları, atopi öyküleri ve ölüm oranları arasında anlamlı fark bulunmadı. Kişisel özellikler incelendiğinde 90 kişinin A tipi kişilik yapısına sahip olduğu ve bunların 51 (\%56,7)'inin B tipine göre daha yüksek ölüm oranıyla kaybedilidği görüldü $(p=0,038)$. Eş zamanlı ARDS gelişimi, sedasyon ihtiyacı ve renal replasman tedavilerinde kişilikler arasında fark yoktu.

Sonuç: Sepsis/septik şok tanısı alan bireyler arasında mortalite A tipi kişilik özelliği olan hastalarda diğer kişilik özelliklerine göre anlamlı olarak artmıştır. Bu sonuçlar, kişisel özelliklerin sepsis/septik şoklu hastalarda hastalık şiddetini ve mortaliteyi tahmin etmede faydalı olabileceğini düşündürmektedir.

Anahtar kelimeler: Kişilik tipleri; mortalite; sepsis; septik şok; yoğun bakım 


\section{INTRODUCTION}

Sepsis continues to be a serious public health problem worldwide. Unfortunately, diagnosis and treatment of this serious disease, with high cost and mortality rates, are still difficult.

By the most recent consensus decisions, sepsis was defined as "life-threatening organ dysfunction caused by an unregulated host response to infection". The clinical criteria for the diagnosis of sepsis are a suspected or documented focus of infection and an acute increase in the SOFA score of two or more. Septic shock is defined as a subset of sepsis in which underlying circulatory and cellular/metabolic abnormalities are deep enough to significantly increase mortality.

In 2014, Vincent et al. found ICU mortality as 25.8\% in patients with sepsis and hospital mortality as $35.3 \%$ (1). This disease with high mortality may result in mental and physical disorders that lead to a decrease in long-term quality of life.

Sepsis is a heterogeneous disease that can be associated with many different types of infections and some other features. The different components of this complex disease process were tried to be explained with the PIRO classification system, which was defined about 10 years ago. In this model, $\mathrm{P}$ is defined as predisposing factors such as genetic, medical history, and clinical context (2).

The genetic variability, comorbidities, and individual traits of the host determine the sepsis phenotype, and possibly explain the differences in responses to the treatment. Grimaldi and Vincent emphasize that, in the future, we will no longer focus on the so-called sepsis medications and we will allow patients with special sepsis phenotypes to be administered the right treatments at the right time (3). In this study, based on this hypothesis, we aimed to reveal personality traits of sepsis/septic shock patients, disease behavior and individual manifestations. In this way, the rapidity of disease progression and the effect of the person's lifestyle and personality traits on the disease process would be revealed.

\section{MATERIALS and METHODS}

\section{Study Plan}

The STROBE guideline was used as a guide for this manuscript. The study was planned as a multi-center, prospective, observational study after obtaining the approval of the local ethics committee of the faculty.
At the end of each month, data from 11 centers were obtained by mail. All intensive care patients hospitalized in intensive care for $>48$ hours between 1 December 2018 and 30 September 2019 with the diagnosis of sepsis or septic shock were included in the study. Patients were excluded from the study, in their second admission. Patients hospitalized for more than 48 hours, were followed up from the date of hospitalization until discharge, or for 28 days if they were not discharged. Sepsis and septic shock were defined according to the Sepsis-3 definitions that was created by the Society of Critical Care Medicine (SCCM) and the European Society of Intensive Care Medicine (ESICM) (4).

\section{Recorded Data}

Patients' demographic characteristics, diagnosis, comorbidities, pre-illness lifestyle characteristics (nutritional characteristics, BMI, blood type, atopy status, alcohol use smoking status, reading habits, tea and coffee consumption frequency) daily activity status (Level 1: Inactive, Level 2: Not enough active, Level 3: Sufficiently active), personality traits (A, B, C, D type personality) (1-3), baseline laboratory values and blood lactate trend, whether the patients developed acute respiratory distress syndrome (ARDS) or not (5) Acute Physiology and Chronic Health Evaluation (APACHE II) and Sequential Organ Failure Assessment (SOFA) scores in the first 24 hours of admission were recorded.

Personality descriptions were made by asking immediate family which one of the personality categories given below they think the patient is closer to;

Type A: Always competing with time, success oriented. These people work and speak fast. They try to do several jobs at the same time. They are hasty, perfectionist, impatient and angry (6).

Type B: They are non-hasty, relaxed, more docile, less competitive people. Calm, quiet, planned, programmed (6).

Type C: They are anxious, overly emotional, overly giving in to emotions, especially their anger, and live with others-oriented people (7).

Type D: People with depression. Anxious, unhappy, tired, unwilling people (8).

The data regarding the infection status of the patients, the body region thought to be the focus of infection and the applied antibiotherapy were recorded. 
Microorganisms accepted as infectious agents were recorded, serology and molecular tests. Inotrope/ vasopressor (used at any time and dose is sufficient) sedative and prior statin usage were recorded. Patients with solid tumors who received chemotherapy, those with hematological malignancies, organ transplant patients, those using corticosteroids (methylprednisolone and its equivalent, taking a dose of "1 $\mathrm{mg} / \mathrm{kg}$ for $>3$ days ) or chemotherapeutic agents for their non-malign diseases, and cases with congenital and acquired immunosuppression (such as HIV virus infection) were accepted as immunosuppressive conditions. If renal replacement therapy was administered, it was recorded.

Among the outcome data of the patients, length of hospital and ICU stay, and mortality were recorded. The length of invasive or non-invasive mechanical ventilation was also recorded.

\section{Statistical Data}

Data were analyzed with IBM SPSS V23 (Chicago, USA). The compliance of the data to normal distribution was examined using the Shapiro Wilk test. Nonnormally distributed data were presented as the median (IQR 25-75), and normally distributed data were presented as mean \pm standard deviation. Categorical data were presented as frequency and percentage. The study population was divided in to two groups according to outcome (survivors and non-survivors). Independent samples t-test from parametric tests was used to compare data with normal distribution according to groups. Kruskal Wallis test and Mann Whitney $U$ test were used to compare quantitative data that did not show normal distribution. Chi-square test was used to compare qualitative data. Bonferroni Method was used in the intergroup post-hoc test in groups of more than two. The efficiency of independent variables according to mortality was examined by univariate regression. Afterwards, multivariate logistic regression analysis was performed with independent variables that were significant in univariate regression. The significance level was taken as $p<0.05$.

\section{RESULTS}

Median age of the 259 patients enrolled in the study was 66 (53-76). When the survivors and non-survivors were compared, the APACHE-II score of the survivors was significantly lower than the non-survivors $[20(15-25), 24$ (15-31)], respectively, $(p=$
0.027). No statistically significant difference was found in the initial SOFA scores between groups [8 $(6-10), 9(6.25-12)]$, respectively, $(p=0.080)$. While median length of stay in IMV was 7 (2-18) days, it was significantly longer in the survivors than in the non-survivors [8 (4.25-18), 5 (1-18), respectively, $\mathrm{p}=$ $0.004)]$. There was no difference in the intensive care stay of the groups, the duration of hospital stay was statistically significantly longer in survivors [28 (1640], 18.5 (10-37), $p=0.005$, respectively] (Table 1). It was found that septic shock developed in 212 $(81.8 \%)$ of 259 sepsis patients.

Median CRP values at the time of diagnosis of sepsis were 120 (54-203.5) $\mathrm{mg} / \mathrm{L}$ in the survived group and $101.2(31-158.75) \mathrm{mg} / \mathrm{L}$ in the non-survived group $(p=0.020)$. In serial lactate measurements, there was no statistically significant difference between the first lactate values in the survived and non-survived groups [2.1 (1.52-3.27), 2,4 (1.47-4.3) $\mathrm{mmol} / \mathrm{L}, \mathrm{p}=$ 0.247 , respectively]. However, when looking at the serial lactate measurements, there was a decline in the $2^{\text {nd }}$ and $3^{\text {rd }}$ lactate values in survivors, which was not observed in non-survivors [1.95 (1.2-2.9) $\mathrm{mmol} / \mathrm{L}$ vs $2.45(1.42-4.35) \mathrm{mmol} / \mathrm{L}, \mathrm{p}=0.020 ; 1.5$ (1.1-2.55), $2.2(1.45-4.3) \mathrm{mmol} / \mathrm{L} \mathrm{p}<0.001$ second and third measurements respectively]. Median body temperature was $38.1(36.8-38.7)^{\circ} \mathrm{C}$ in the survived group at the time of sepsis diagnosis, while it was 37.1 (36.6$38.4)^{\circ} \mathrm{C}$ in the non-survived group $(\mathrm{p}=0.020)$. When the parameters were evaluated at the time of diagnosis of septic shock, median SOFA score in survivors was statistically significantly lower than the non-survivors [10 (8-12), 11 (9-14), respectively, $\mathrm{p}=0.003$ ].

Of the sepsis patients, 157 (60.7\%) were admitted with surgical diagnoses, 102 (39.3\%) for medical causes. Although a vast majority of the patients had more than one reason for admission to intensive care, the most common reasons for hospitalization in 259 patients were infectious in $114(44 \%)$ patients and respiratory in $106(40.9 \%)$ patients. There was no statistically significant difference in mortality among primary hospitalization diagnoses. Among the patients screened for 45 different comorbidities, 24 $(0.9 \%)$ of them did not have any comorbidity. The most common comorbidities were hypertension in $111(42.8 \%)$ patients, diabetes mellitus in $54(20.8 \%)$ patients, coronary artery disease in 48 (18.5\%) patients, and heart failure in $32(12.3 \%)$ patients, respectively. No statistically significant effect of any comorbidity on mortality was detected. 
Pehlivanlar Küçük M, Küçük AO, Kömürcü Ö, Dikmen Y, Kadıoğlu M, Uzan ÇA, et al.

Table 1. Comparison of quantitative data according to mortality

\begin{tabular}{|c|c|c|c|c|}
\hline & Total & Survived & Non-survived & $\mathbf{p}$ \\
\hline Beginning & $\mathrm{n}=259$ & $\mathrm{n}=143$ & $\mathrm{n}=116$ & \\
\hline External service/Hospital stay duration & $2(0-8)$ & $2(0-8)$ & $2(0-8)$ & 0.705 \\
\hline Age (year) & $66(53-76)$ & $65(48-74)$ & $69(58-77.75)$ & 0.067 \\
\hline Height $(\mathrm{cm})$ & $169(160-175)$ & $168(160-175)$ & $170(160-175)$ & 0.649 \\
\hline Weight (kg) & $70(60-80)$ & $70(60-80)$ & $70(60-80.75)$ & 0.656 \\
\hline APACHE II & $22(15-28)$ & $20(15-25)$ & $24(15-31)$ & 0.027 \\
\hline SOFA & $8(6-11)$ & $8(6-10)$ & $9(6.25-12)$ & 0.080 \\
\hline Hospital application in the last year & $4(2-10)$ & $3(2-10)$ & $4(2-10)$ & 0.121 \\
\hline Smoke (Package/day) & $0(0-1)$ & $0(0-1)$ & $0(0-1)$ & 0.473 \\
\hline \multicolumn{5}{|l|}{ Outcome } \\
\hline The number of total Atb day & $17(10-30)$ & $18(10-30)$ & $15.5(8-30.5)$ & 0.232 \\
\hline Non-IMV stay duration (day) & $0(0-2)$ & $0(0-2)$ & $0(0-2.75)$ & 0.493 \\
\hline IMV stay duration (day) & $7(2-18)$ & $5(1-18)$ & $8(4.25-18)$ & 0.004 \\
\hline Intensive care stay (day) & $12(7-25)$ & $12(6-25)$ & $11.5(7-22.75)$ & 0.491 \\
\hline Hospital stay duration (day) & $23(13-39)$ & $28(16-40)$ & $18.5(10-37)$ & 0.005 \\
\hline
\end{tabular}

When the sepsis factors were examined, pathogenic microorganism was detected in 223 (86.1\%) patients, while no pathogen was detected in 36 (13.9\%) patients. Infection focus was the respiratory tract in $89(34.4 \%)$, blood circulation in 49 (18.9\%), and urinary tract in 27 (10.4) patients. While Gr (-) microorganism was detected as the causative organism in 119 (45.9\%) patients, Gr (+) in 79 (30.5\%) patients, and other microorganisms were detected in 28 (10.8\%) patients. In 212 septic shock patients, the most common focus was respiratory tract with 75 (35.4\%) patients.

When phenotypic characteristics were compared, 69 (47.9) of the survivors were males, while 75 (52.1\%) of the non-survivors were males, and mortality was significantly higher in male compared to female patients $(p=0.008)$. Considering personal characteristics, mortality was the highest in type A among the four personality traits. Mortality was observed in 51 (56.7\%) patients with type A personality, it was observed in $41(36.6 \%)$ patients with type B personality $(p=0.038)$. Details on the comparison of phenotypic characteristics were given in Table 2 .

In comparison of the patients according to personality types, it was found that the median ages of all four groups were similar to one another $(p=0.227)$. The
APACHE and SOFA scores of the four groups were similar to one another $(p=0.836, p=0.640$, respectively). The examination of outcome data showed no significant differences in the duration of non-IMV, IMV, intensive care, and hospital stay in all four groups $(p=0.910, p=0.610, p=0.627, p=0.878$, respectively). When the baseline values for sepsis were compared, CRP value was the highest with 110 (51.7-190) $\mathrm{mg} / \mathrm{L}$ in the type B personality and the lowest with 76.5 (44.6-159.9) mg/L in type D personality. When serial lactate follow-ups were compared, there was a statistically significant difference in the initial $1^{\text {st }}$ lactate values $(p=0.014)$. This significance was mainly due to the high median lactate value of $2.6(1.75-4.7) \mathrm{mmol} / \mathrm{L}$ in the type A personality and the low median lactate value of 1.75 (1.27-2.52) $\mathrm{mmol} / \mathrm{L}$ in the type $\mathrm{D}$ personality. Comparisons according to personality types, outcomes and initial parameters are shown in Table 3.

No statistically significant difference in terms of personality types was found in the development of ARDS, need for vasopressor, need for sedation, administration of RRT, vitamin support. However, systemic steroid use was higher in type A personality $(63.3 \%)$, when compared with type B $(43.8 \%)(p=$ 0.041 ) (Table 4). 
Table 2. Comparison of mortality in sepsis according to phenotypic characteristics

\begin{tabular}{|c|c|c|c|c|}
\hline & Survived & Non-survived & Total & $\mathbf{p}$ \\
\hline Parameter & $\mathrm{n}(\%)$ & $\mathrm{n}(\%)$ & n $(\%)$ & \\
\hline \multicolumn{5}{|l|}{ Sex } \\
\hline Female & $74(64.3)$ & $41(35.7)$ & $115(100)$ & \multirow{2}{*}{0.008} \\
\hline Male & $69(47.9)$ & $75(52.1)$ & $144(100)$ & \\
\hline \multicolumn{5}{|l|}{ Blood group } \\
\hline 0 & $47(54)$ & $40(46)$ & 87 (100) & \multirow{4}{*}{0.478} \\
\hline A & $69(59)$ & $48(41)$ & $117(100)$ & \\
\hline B & $17(44.7)$ & $21(55.3)$ & $38(100)$ & \\
\hline $\mathrm{AB}$ & $10(58.8)$ & $7(41.2)$ & $17(100)$ & \\
\hline \multicolumn{5}{|l|}{ Rh Factor } \\
\hline- & $17(42.5)$ & $23(57.5)$ & $40(100)$ & \multirow{2}{*}{0.113} \\
\hline+ & $126(57.5)$ & $93(42.5)$ & $219(100)$ & \\
\hline \multicolumn{5}{|l|}{ Medical history } \\
\hline No & $47(51.1)$ & $45(48.9)$ & $92(100)$ & \multirow{2}{*}{0.322} \\
\hline Yes & $96(57.5)$ & $71(42.5)$ & $167(100)$ & \\
\hline \multicolumn{5}{|l|}{ RI history } \\
\hline No & $106(55.5)$ & $85(44.5)$ & $191(100)$ & \multirow{2}{*}{0.877} \\
\hline Yes & $37(54.4)$ & $31(45.6)$ & $68(100)$ & \\
\hline \multicolumn{5}{|l|}{ Atopy existence } \\
\hline No & $131(55.5)$ & $105(44.5)$ & $236(100)$ & \multirow[t]{2}{*}{0.93} \\
\hline Yes & $12(52.2)$ & $11(47.8)$ & $23(100)$ & \\
\hline \multicolumn{5}{|l|}{ Familial genetic disease } \\
\hline No & $121(56.3)$ & $94(43.7)$ & $215(100)$ & \multirow{2}{*}{0.551} \\
\hline Yes & $22(50)$ & $22(50)$ & $44(100)$ & \\
\hline \multicolumn{5}{|l|}{ Cancer in the family } \\
\hline No & $91(57.6)$ & $67(42.4)$ & $158(100)$ & \multirow{2}{*}{0.335} \\
\hline Yes & $52(51.5)$ & $49(48.5)$ & $101(100)$ & \\
\hline \multicolumn{5}{|l|}{ Frequent diet history } \\
\hline No & $126(53.8)$ & $108(46.2)$ & $234(100)$ & \multirow{2}{*}{0.254} \\
\hline Yes & $17(68)$ & $8(32)$ & $25(100)$ & \\
\hline \multicolumn{5}{|l|}{ Immunosuppression } \\
\hline No & $102(60)$ & $68(40)$ & $170(100)$ & \multirow{2}{*}{0.032} \\
\hline Yes & $41(46.1)$ & $48(53.9)$ & $89(100)$ & \\
\hline \multicolumn{5}{|l|}{ Smoke } \\
\hline No & $79(56.8)$ & $60(43.2)$ & $139(100)$ & \multirow{2}{*}{0.572} \\
\hline Yes & $64(53.3)$ & $56(46.7)$ & $120(100)$ & \\
\hline \multicolumn{5}{|l|}{ Active sport } \\
\hline No & $127(54.7)$ & $105(45.3)$ & $232(100)$ & 0809 \\
\hline Yes & $16(59.3)$ & $11(40.7)$ & $27(100)$ & 0.009 \\
\hline Reading habit & & & & \\
\hline No & $84(56.4)$ & $65(43.6)$ & $149(100)$ & \\
\hline Yes & $59(53.6)$ & $51(46.4)$ & $110(100)$ & 0.661 \\
\hline Diet & & & & \\
\hline High carbohydrate & $72(60)$ & $48(40)$ & $120(100)$ & \\
\hline High protein & $41(52.6)$ & $37(47.4)$ & $78(100)$ & 0185 \\
\hline Mediterranean type & $30(51.7)$ & $28(48.3)$ & $58(100)$ & 0.185 \\
\hline Vegan/vegetarian & $0(0)$ & $3(100)$ & $3(100)$ & \\
\hline
\end{tabular}


Pehlivanlar Küçük M, Küçük AO, Kömürcü Ö, Dikmen Y, Kadıoğlu M, Uzan ÇA, et al.

Table 2. Comparison of mortality in sepsis according to phenotypic characteristics (continue)

\begin{tabular}{|c|c|c|c|c|}
\hline & Survived & Non-survived & Total & $\mathbf{p}$ \\
\hline Parameter & n $(\%)$ & n (\%) & n $(\%)$ & \\
\hline \multicolumn{5}{|c|}{ Coffee consumption } \\
\hline 0 & $90(55.2)$ & $73(44.8)$ & $163(100)$ & \multirow{4}{*}{0.968} \\
\hline $1-2$ & $44(54.3)$ & $37(45.7)$ & $81(100)$ & \\
\hline $3-4$ & $8(61.5)$ & $5(38.5)$ & $13(100)$ & \\
\hline$>5$ & $1(50)$ & $1(50)$ & $2(100)$ & \\
\hline \multicolumn{5}{|c|}{ Tea consumption } \\
\hline 0 & $5(38.5)$ & $8(61.5)$ & $13(100)$ & \multirow{4}{*}{0.653} \\
\hline $1-2$ & $53(55.2)$ & $43(44.8)$ & $96(100)$ & \\
\hline $3-4$ & $42(56)$ & $33(44)$ & $75(100)$ & \\
\hline$>5$ & $43(57.3)$ & $32(42.7)$ & $75(100)$ & \\
\hline \multicolumn{5}{|c|}{ Daily activity } \\
\hline Level 1 & $55(57.3)$ & $41(42.7)$ & $96(100)$ & \multirow{3}{*}{0.857} \\
\hline Level 2 & $46(54.8)$ & $38(45.2)$ & $84(100)$ & \\
\hline Level 3 & $42(53.2)$ & $37(46.8)$ & 79 (100) & \\
\hline \multicolumn{5}{|l|}{ Personal trait } \\
\hline Type A & $39(43.3)^{\mathrm{a}}$ & $51(56.7)$ & $90(100)$ & \multirow{4}{*}{0.038} \\
\hline Type B & $71(63.4)^{b}$ & $41(36.6)$ & $112(100)$ & \\
\hline Type C & $22(59.5)^{a, b}$ & $15(40.5)$ & $37(100)$ & \\
\hline Type D & $11(55)^{a, b}$ & $9(45)$ & $20(100)$ & \\
\hline \multicolumn{5}{|c|}{$\begin{array}{l}\text { RI: Respiratory insufficiency. } \\
\text { Frequencies are expressed as } n(\%) \text {. Consumption habits are expressed in the form of daily cups. There is a statistically significant limit of } 0.05 \text { and } \\
\text { bold } p \text { values represent statistical significance. } \\
\text { Each superscript letter denotes a subset of personal trait categories whose row proportions do not differ significantly from each other at the } 0.05 \text { level. }\end{array}$} \\
\hline
\end{tabular}

Post-hoc Adjusted Bonferroni method was used to analyze the significance of personality traits according to mortality $(p=0.038)$. After the analysis, it was determined that the significant difference was caused by type $A$ and type $B$ personal traits. $C$ type and $D$ type personal traits were determined similar with both A and B personal traits (Table 2). Afterwards, univariate and multivariate logistic regression analysis were evaluated on a total of 202 patients of which 90 in type $A$ and 112 in type B. In the univariate analysis of independent variables according to mortality of 202 patients, gender and personality traits were determined as statistically significant parameters on mortality. A multivariate logistic regression analysis was performed by adding the APACHE II score, and similarly, gender and personality trait (being male rather than female, being type $B$ rather than type A) were determined as statistically significant independent variables on mortality (Table 5).

\section{DISCUSSION}

The hypothesis that personality affects the development and course of physical diseases emerged has many times and in many forms throughout the history of medicine (9). Research on personality and health can provide useful interventions for the prevention and management of physical illnesses. In our study, based on this hypothesis, the relationship between sepsis/ septic shock states and personality types, was examined. As a result of this study, mortality rates significantly increased in patients with type A personality trait among individuals diagnosed with sepsis/septic shock compared to other personality traits (B, C and D). Behavior patterns suggest that personality influences daily habits related to health (e.g. smoking, diet, exercise). A wide variety of health conditions are associated with major personality traits, and these factors may mediate the relationship between personality and illness (10). Numerous previous studies have revealed the Type A behavior pattern (TABP) as a coronary risk factor (11-14). Houston have shown that Type A individuals have larger cardiovascular and neuroendocrine responses to a variety of stressors (15).

Sepsis is defined as "life-threatening organ dysfunction caused by a unregulated host response to infection", while septic shock is defined as a subset of sepsis in which underlying circulatory and cellular/ 
Table 3. Comparison of quantitative data according to character traits

\begin{tabular}{|c|c|c|c|c|c|}
\hline & Type A & Type B & Type C & Type D & p \\
\hline \multicolumn{6}{|l|}{ Beginning } \\
\hline $\begin{array}{l}\text { External service/Hospital stay } \\
\text { Duration (day) }\end{array}$ & $1(0-7.25)$ & $2(0-9.5)$ & $2(0-6.5)$ & $5.5(1.25-13.5)$ & 0.219 \\
\hline Age (year) & $68(58.75-78)$ & $66(49.25-75.75)$ & $64(41-74)$ & $70(55-75.5)$ & 0.227 \\
\hline Height $(\mathrm{cm})$ & $170(163.75-176)$ & $170(160-175)$ & $160(155-168.5)$ & $168(160-174.25)$ & $<0.001$ \\
\hline Weight (kg) & $70(60-85)$ & $70(60-80)$ & $66(55-75)$ & $76(60.5-84)$ & 0.310 \\
\hline APACHE II & $22.5(14.75-29)$ & $21.5(17-28)$ & $20(13.5-25)$ & $23(11.25-27.75)$ & 0.836 \\
\hline SOFA & $8(6-12)$ & $9(6-11)$ & $8(6-10)$ & $6.5(5-12)$ & 0.640 \\
\hline Hospital application in a year & $4(2-10)$ & $4(2-8)$ & $4(2-15)$ & $3.5(2-10)$ & 0.637 \\
\hline Smoke (Package/day) & $0.5(0-1)$ & $0.25(0-1)$ & $0(0-0.75)$ & $0(0-0.375)$ & 0.010 \\
\hline \multicolumn{6}{|l|}{ Outcome } \\
\hline Total atb day & $17(10-30.25)$ & $18.5(9-31.75)$ & $16(9.5-27)$ & $15(10-34)$ & 0.966 \\
\hline Non-IMV duration (Day) & $0(0-3)$ & $0(0-2)$ & $0(0-2)$ & $0(0-5)$ & 0.910 \\
\hline IMV duration (day) & $8(2.75-18)$ & $7(3-18)$ & $7(3.5-17.5)$ & $3.5(1.25-14.25)$ & 0.610 \\
\hline Intensive care duration (Day) & $13(7-24.25)$ & $11.5(7-25.75)$ & $11(6-27)$ & $8.5(4.25-23.5)$ & 0.627 \\
\hline Hospital duration (Day) & $21(14-36.25)$ & $23(12-39.5)$ & $28(13.5-43.5)$ & $20.5(14.25-37.25)$ & 0.878 \\
\hline \multicolumn{6}{|l|}{ Sepsis } \\
\hline $\mathrm{CRP}(\mathrm{mg} / \mathrm{L})$ & $79.78(31.9-149.5)$ & $110(51.7-190)$ & $167(76.3-252)$ & $76.5(44.6-159.9)$ & 0.012 \\
\hline WBC $\left(\times 10^{9} / \mathrm{L}\right)$ & $13.6(6.7-17.3)$ & $12.8(8.84-16.85)$ & $11.9(4.6-18.68)$ & $14.6(10.7-18.5)$ & 0.712 \\
\hline Neutrophil \% & $87.35(80.5-92.0)$ & $85.8(78.1-90.9)$ & $83.1(72.4-90)$ & $87.8(85.1-91.1)$ & 0.374 \\
\hline Lymphocyte \% & $6.71(4.1-11.1)$ & $7.4(4-13.8)$ & $8.4(4-24.1)$ & $4.7(3.3-7.7)$ & 0.150 \\
\hline Eosinophil \% & $0.03(0-0.3)$ & $0.2(0-0.9)$ & $0.1(0-1.1)$ & $0.1(0-0.3)$ & 0.080 \\
\hline Glucose (mg/dl) & $156(114.5-208)$ & $167(123.5-218.5)$ & $147(118-215)$ & $155(136.5-172.5)$ & 0.682 \\
\hline Albumin $(\mathrm{g} / \mathrm{dl})$ & $2.8(2.4-3.3)$ & $2.7(2.2-3.0)$ & $2.7(2.3-3.5)$ & $2.7(2.2-3.6)$ & 0.588 \\
\hline Procalcitonin (ng/ml) & $2.5(0.96-11.58)$ & $2.08(1.03-7.87)$ & $2.68(0.82-7.7)$ & $2(0.632-3.88)$ & 0.676 \\
\hline Uric acid $(\mathrm{g} / \mathrm{dl})$ & $5.25(4.2-6.5)$ & $4.2(3.2-6.05)$ & $7.2(4.5-9.8)$ & $5.75(3.2-9.4)$ & 0.109 \\
\hline BUN (mg/L) & $40(28-61)$ & $45(27-65)$ & $46.5(31-63)$ & $46.15(24.2-79.5)$ & 0.620 \\
\hline Creatinine (mg/dl) & $1.38(0.8-1.98)$ & $1.175(0.7-2.65)$ & $1.26(0.7-1.7)$ & $1.18(0.71-1.97)$ & 0.754 \\
\hline Lactate $1(\mathrm{mmol} / \mathrm{L})$ & $2.6(1.75-4.7)$ & $2.3(1.4-3.3)$ & $2(1.4-2.7)$ & $1.75(1.27-2.52)$ & 0.014 \\
\hline Lactate $2(\mathrm{mmol} / \mathrm{L})$ & $2.4(1.45-3.9)$ & $2.1(1.2-3.47)$ & $2.1(1.4-2.9)$ & $1.7(1.05-2.6)$ & 0.190 \\
\hline Lactate 3 (mmol/L) & $1.9(1.3-3.8)$ & $2(1.2-3.65)$ & $1.85(1.32-2.27)$ & $1.4(0.9-2.42)$ & 0.297 \\
\hline Lactate $4(\mathrm{mmol} / \mathrm{L})$ & $1.8(1.1-2.8)$ & $1.6(1-3.75)$ & $1.5(0.95-2.4)$ & $1.5(1.1-2.3)$ & 0.717 \\
\hline $\operatorname{ALT}(\mathrm{u} / \mathrm{L})$ & $27(14-46)$ & $23(14.1-48)$ & $31(13.5-79)$ & $26.5(13.25-85.25)$ & 0.927 \\
\hline $\mathrm{AST}(\mathrm{u} / \mathrm{L})$ & $33(19-68)$ & $30(21-52)$ & $34(24.7-99.5)$ & $48.5(19.25-107.75)$ & 0.648 \\
\hline SOFA & $8(5-10)$ & $9(5-11)$ & $8(6-10)$ & $6.5(4.75-10.25)$ & 0.589 \\
\hline Body temperature $\left({ }^{\circ} \mathrm{C}\right)$ & $36.9(36.5-38.1)$ & $37.7(36.7-38.5)$ & $37.9(36.8-38.3)$ & $37.6(36.6-38.2)$ & 0.077 \\
\hline Pulse (pulse/min) & $110(96-120)$ & $110(100-128)$ & $101(86-120)$ & $110(93-130)$ & 0.178 \\
\hline Respiratory rate (/min) & $24(0-30)$ & $24(0-30)$ & $25(16-30)$ & $19.5(0-23.5)$ & 0.290 \\
\hline
\end{tabular}


Pehlivanlar Küçük M, Küçük AO, Kömürcü Ö, Dikmen Y, Kadıoğlu M, Uzan ÇA, et al.

Table 4. Comparison of morbidity and interventions according to personal characteristics

\begin{tabular}{|c|c|c|c|c|c|c|}
\hline & Type A & Type B & Type C & Type D & Total & $\mathbf{p}$ \\
\hline Parameter & n (\%) & n (\%) & n (\%) & n (\%) & & \\
\hline \multicolumn{7}{|c|}{ ARDS development } \\
\hline No & $63(70)$ & $84(75)$ & $30(81.1)$ & $16(80)$ & $193(74.5)$ & \multirow{2}{*}{0.544} \\
\hline Yes & $27(30)$ & $28(25)$ & 7 (18.9) & $4(20)$ & $66(25.5)$ & \\
\hline \multicolumn{7}{|c|}{ Vasopressor need } \\
\hline No & $16(17.8)$ & $19(17)$ & $8(21.6)$ & $7(35)$ & $50(19.3)$ & \multirow{2}{*}{0.282} \\
\hline Yes & $74(82.2)$ & $93(83)$ & $29(78.4)$ & $13(65)$ & $209(80.7)$ & \\
\hline \multicolumn{7}{|c|}{ Sedation need } \\
\hline No & $17(18.9)$ & $34(30.4)$ & $12(32.4)$ & $8(40)$ & $71(27.4)$ & \multirow{2}{*}{0.120} \\
\hline Yes & $73(81.1)$ & $78(69.6)$ & $25(67.6)$ & $12(60)$ & $188(72.6)$ & \\
\hline \multicolumn{7}{|c|}{ Systemic steroid } \\
\hline No & $33(36.7)$ & $63(56.3)$ & $19(51.4)$ & $11(55)$ & $126(48.6)$ & \multirow{2}{*}{0.042} \\
\hline Yes & $57(63.3)$ & $49(43.8)$ & $18(48.6)$ & $9(45)$ & $133(51.4)$ & \\
\hline \multicolumn{7}{|l|}{ RRT } \\
\hline No & $57(63.3)$ & $81(72.3)$ & $27(73)$ & $15(75)$ & $180(69.5)$ & \multirow{2}{*}{0.470} \\
\hline Yes & $33(36.7)$ & $31(27.7)$ & $10(27)$ & $5(25)$ & $79(30.5)$ & \\
\hline \multicolumn{7}{|c|}{ Vitamin support } \\
\hline No & $55(61.1)$ & $76(67.9)$ & $25(67.6)$ & $18(90)$ & $174(67.2)$ & \multirow{3}{*}{0.100} \\
\hline Yes & 35 (38.9) & $36(32.1)$ & $12(32.4)$ & $2(10)$ & $85(32.8)$ & \\
\hline Total & $90(100)$ & $112(100)$ & 37 (100) & $20(100)$ & 259 (100) & \\
\hline \multicolumn{7}{|c|}{$\begin{array}{l}\text { Frequencies are expressed as } n \text { (\%), Consumption habits are expressed in the form of daily cups. There is a statistically significant limit of } 0.05 \text { an } \\
\text { bold } p \text { values represent statistical significance. }\end{array}$} \\
\hline
\end{tabular}

Table 5. Regression analysis of independent variables affecting mortality in patients with sepsis

\begin{tabular}{|lcccc|} 
& \multicolumn{2}{c}{ Univariant } & & Multivariant \\
\hline \multicolumn{1}{c}{ OR $(\mathbf{\% 9 5} \mathbf{~ C l})$} & $\mathbf{p}$ & OR (\%95 Cl) & p \\
\hline Sex* & $2.125(1.189-3.789)$ & 0.011 & $2.013(1.111-3.650)$ & 0.021 \\
Personal Trait** & $0.442(0.250-0.779)$ & 0.005 & $0.446(0.250-0.795)$ & 0.006 \\
APACHE II & & & $1.017(0.987-1.047)$ & 0.278 \\
\hline * Sex: Being male rather than female. & & & \\
** Being a type B personality rather than Type A. & & & \\
\hline
\end{tabular}

metabolic abnormalities are deep enough to significantly increase mortality (4). The "host" characteristics, which are the subject of this definition, should of course be important in the disease response. Potentially stressful living conditions affect the way the person copes with them, neuroendocrine response to stress, immune function, inflammation, and cardiovascular responses, and this contributes to the development of the disease (16).

Our intensive care patients, who were included in the study, were questioned in terms of their life styles besides their personality traits. There was no significant difference between the patients' daily activity, tea and coffee consumption, reading habits, smoking habits, blood groups, atopy histories, and septic shock and mortality. This result may be associated with the small number of patients enrolled in the study and the fact that the information was obtained from relatives (due to insufficient or incomplete information), not patients, due to their clinical status. On the other hand, a comprehensive comparison could not be made due to the lack of data on this subject in patients with sepsis in the literature.

Type A and Type B personality were first observed by two cardiologists Meyer Friedman and Rosenman. The idea arose for the first time when the upholsterer 
who was repairing the living room chairs said that most of the chairs were only torn from the front. From this situation, both cardiologists realized that many of the patients with cardiac diseases were worried and had a hard time waiting for their examinations. Using this observation as a starting point and based on their own clinical practice, Friedman and Rosenman concluded that their patients exhibited two very different behavioral patterns (6). Due to Friedman and Rosenman's study, it is often thought that Type A persons experience the worst consequences of stress such as heart attacks. More than impatience, which is the characteristic feature of Type A, anger and hostile feelings cause heart problems (17).

As a result of our study, it was observed that individuals with A-type personality structure have higher severity of their response to infection, as well as the cardiac risks they carry, and disease control is more difficult for them. In addition to the increased mortality of sepsis/septic shock in these individuals, the need for steroids increased significantly compared to the $\mathrm{B}, \mathrm{C}$ and D type personalities. In our study, while 57 (63.3\%) of 90 patients with A-type personality trait needed systemic steroids, only $49(43.8 \%)$ of 112 people with B-type personality traits needed steroids. Exposure to stress initiates a series of responses in the organism. These responses are aimed at increasing survival. This condition, called the stress response, is governed mainly by two systems: the sympathetic nervous system and the hypothalamo-pituitary-adrenal axis (HPA). As a result of the activation of HPA axis, steroid synthesis increases and steroid regulates the immune, cardiovascular and metabolic changes required to cope with stress (18). In a septic patient, steroids, both in the HPA axis and intracellularly, are very different from those in a healthy person. Impairment in cortisol production and its effects on tissue level and relative cortisol insufficiency occur. The results of our study show that inadequacy in stress response is more prominent in Type A personality.

The failure of new treatment strategies in multi-center studies led to the need to focus on the biological phenotype of the individual and to adopt a personalized treatment approach.

It is becoming increasingly clear that standard physiological and biochemical variables are associated with the patient's underlying biological phenotype/ endotype/subendotype. Although biomarker studies in sepsis and ARDS are beneficial in some subgroups to the parameter examined (e.g., fluid, PEEP, corticosteroids, statins), they reveal variable host responses by harming others (19-21). However, drug and device trials are often based on the "one-size-fits all" regimen, without considering the underlying biological phenotype of the patient.

The limitations of our study were first based on the interpretations of the patients' personality, the observational descriptions and statements of the first-degree relatives of the patient. There was no professional definition. Second, data could not be compared between sepsis and septic shock conditions due to the small number of patients with only sepsis diagnosis. Due to the small number of patients, subgroup data could not be compared.

The importance of individual variability in organism response to disease and treatment success in patients with sepsis/septic shock is supported observationally and by a large number of literature data. As a result of our study, mortality increased significantly in patients with A-type personality trait among individuals diagnosed with sepsis/septic shock compared to other personality traits. Blood lactate levels increased significantly in the early period of these patients and they required more steroid due to severity of the disease. While organizing sepsis/septic shock treatments, disease severity and mortality can be predicted according to personality traits. These results should be supported by studies with higher number of patients and with different patient subgroups.

Ethical Committee Approval: The ethical approval for this study was obtained from Ondokuz Mayis University Clinical Research Ethical Committee (Decision No: B.30.2.ODM.0.2008/1932, Date: 19.10.2018).

\section{CONFLICT of INTEREST}

The authors of this meta-analysis declare that they have no conflict of interest.

\section{AUTHORSHIP CONTRIBUTIONS}

Concept/Design: MPK, AOK, OK, YD, FÜ

Analysis/Interpretation: MPK, AOK

Data acqusition: All of authors

Writing: MPK, AOK, ÖK, FÜ

Clinical Revision: MPK, AOK, ÖK, YD, FÜ

Final Approval: All of authors 


\section{REFERENCES}

1. Vincent IL, Marshall JC, Namendys-Silva SA, François B, Martin-Loeches I, Lipman J, et al. Assessment of the worldwide burden of critical illness: The Intensive Care Over Nations (ICON) audit. Lancet Respir Med 2014 May 1; 2(5): $380-6$

2. Levy MM, Fink MP, Marshall JC, Abraham E, Angus D, Cook D, et al. 2001 SCCM/ESICM/ACCP/ATS/SIS International Sepsis Definitions Conference. Crit Care Med 2003 Apr 1; 31(4): 1250-6.

3. Grimaldi $D$, Vincent IL. Clinical trial research in focus: rethinking trials in sepsis [Internet]. Vol. 5, The Lancet Respiratory Medicine. Lancet Publishing Group; 2017; 610-1.

4. Singer $M$, Deutschman CS, Seymour C, Shankar-Hari $M$, Annane $D$, Bauer $M$, et al. The third international consensus definitions for sepsis and septic shock (sepsis-3) [Internet]. Vol. 315, JAMA - Journal of the American Medical Association. American Medical Association; 2016; 801-10.

5. Ranieri VM, Rubenfeld GD, Thompson BT, Ferguson ND, Caldwell E, Fan $E$, et al. Acute respiratory distress syndrome: The Berlin definition. JAMA - I Am Med Assoc 2012 Jun 13; 307(23): 2526-33.

6. Griffin RW, Moorhead G. Organizational Behavior. 10th ed. Boston: Cengage Learning; 2011. 463 p.

7. Cardona Serna E, Jaramillo A, Díaz Facio Lince V. Relación entre la personalidad tipo c y el cáncer. Relationship between type $C$ Personality and cancer, state of the art. Psicoespacios Rev virtual la Inst Univ Envigado 2013 Jun 20; 7(10): 66-92.

8. Gilmour J, Williams L. Type D personality is associated with maladaptive health-related behaviours. I Health Psychol 2012 May; 17(4): 471-8.

9. McMahom CE. The role of imagination in the disease process: Pre-Cartesian history (the role of imagination in the disease process). Psychol Med 1976; 6(2): 179-84.

10. Booth-Kewley S, Vickers RR. Associations between major domains of personality and health behavior. I Pers 1994; 62(3): 281-98.

11. Cooper T, Detre T, Weiss SM. Coronary-prone behavior and coronary heart disease: A critical review [Internet]. Vol. 63, Circulation. Circulation 1981; 1199-215.
12. Dembroski TM, MacDougall JM, Costa PT, Grandits GA. Components of hostility as predictors of sudden death and myocardial infarction in the Multiple Risk Factor Intervention Trial. Psychosom Med 1989; 51(5): 514-22.

13. Hecker MHL, Chesney MA, Black GW, Frautschi N. Coronary-prone behaviors in the Western Collaborative Group Study. Psychosom Med 1988; 50(2): 153-64.

14. Matthews KA, Glass DC, Rosenman RH, Bortner RW. Competitive drive, pattern a, and coronary heart disease: A further analysis of some data from the Western Collaborative Group Study. I Chronic Dis 1977; 30(8): 489-98.

15. Houston BK. Personality dimensions in reactivity and cardiovascular disease. In: Handbook of research methods in cardiovascular behavioral medicine. Boston: Springer; 1989; 495-509.

16. Schneiderman N, Ironson G, Siegel SD. Stress and health: Psychological, behavioral, and biological determinants [Internet]. Vol. 1, Annual Review of Clinical Psychology. Annu Rev Clin Psychol 2005; 607-28.

17. Luthans F. Organizational Behavior, international edition. istanbul: Literatür Yayıncilık. 1995.

18. Carrasco GA, Van De Kar LD. Neuroendocrine pharmacology of stress. Eur J Pharmacol 2003 Feb 28; 463(1-3): 235-72.

19. Calfee CS, Delucchi K, Parsons PE, Thompson BT, Ware $L B$, Matthay MA. Subphenotypes in acute respiratory distress syndrome: Latent class analysis of data from two randomised controlled trials. Lancet Respir Med 2014; 2(8): 611-20.

20. Wong HR, Atkinson SJ, Cvijanovich NZ, Anas N, Allen GL, Thomas NJ, et al. Combining Prognostic and Predictive Enrichment Strategies to Identify Children with Septic Shock Responsive to Corticosteroids. Crit Care Med 2016 Oct 1; 44(10): e1000-3.

21. Famous KR, Delucchi $K$, Ware LB, Kangelaris KN, Liu KD, Thompson BT, et al. Acute respiratory distress syndrome subphenotypes respond differently to randomized fluid management strategy. Am J Respir Crit Care Med. 2017 Feb 1; 195(3): 331-8. 